\title{
水素処理法によるチタン系材料の結晶粒超微細化
}

\author{
中東 潤1 \\ 住本晃史 1 ,*3 \\ 高畑 公 輔1,*1 \\ 鶴 健太郎 $1, * 2$ \\ 吉村博 文 ${ }^{1}$ \\ 堀村弘 幸 ${ }^{2}$
}

\author{
1福山大学工学部機械システム工学科 \\ 2株式会社本田技術研究所 \\ J. Japan Inst. Metals, Vol. 70, No. 2 (2006), pp. 204-211
}

(C) 2006 The Japan Institute of Metals

\section{Ultra-Fine Grain Refinement of Titanium Materials by Hydrogen Treatment}

Jun Nakahigashi ${ }^{1}$, Kosuke Takahata ${ }^{1, * 1}$, Kentaro Tsuru, ${ }^{1, * 2}$,

Terufumi Sumimoto ${ }^{1, * 3}$, Hirofumi Yoshimura ${ }^{1}$ and Hiroyuki Horimura ${ }^{2}$

${ }^{1}$ Department of Mechanical Engineering, Faculty of Engineering, Fukuyama University, Fukuyama 729-0292

${ }^{2}$ Honda Research and Development Co., Ltd., Asaka 351-8555

Hydrogen treatment is one of the few possible methods for producing a fine-grain size of 0.3 to $0.5 \mu \mathrm{m}$ in $\alpha+\beta$ Ti- $6 \mathrm{Al}-4 \mathrm{~V}$ alloys. The process of hydrogen treatment involves hydrogen absorption, quenching, hot rolling and hydrogen desorption. However, ultra-fine grain refinement of other titanium materials by this treatment has not yet been examined. In this study, the optimum hydrogen treatment conditions for ultra-fine grain refinement of two phase $\alpha+\beta$ Ti-3Al-2.5V, two phase $\alpha+\beta$ Ti- $1 \mathrm{Fe}^{-}$ 0.350 and single phase $\alpha$ titanium were investigated in order to expand the application of this effective treatment to the grain refinement of other titanium materials. Tensile tests were also carried out at room and high temperatures to investigate the tensile properties of the grain-refined materials. The experimental results that were obtained are as follows.

An ultra-fine grain size in the range of 0.5 to $1 \mu \mathrm{m}$ was produced in the Ti-3Al- $2.5 \mathrm{~V}$ and $\mathrm{Ti}-1 \mathrm{Fe}-0.35 \mathrm{O}$ alloys by controlling the hydrogen treatment conditions, particularly the content of hydrogen absorbed and hot rolling conditions. However, ultra-fine grain refinement of pure titanium was not observed. It is thought that one of the reasons for this lies with the differences in the morphology of the martensite obtained when quenching $\mathrm{Ti}-3 \mathrm{Al}-2.5 \mathrm{~V}$ and $\mathrm{Ti}-1 \mathrm{Fe}-0.35 \mathrm{O}$ alloys. The proof stress of the ultrafine-grained $\mathrm{Ti}-3 \mathrm{Al}-2.5 \mathrm{~V}$ and $\mathrm{Ti}-1 \mathrm{Fe}-0.35 \mathrm{O}$ alloys was improved by the hydrogen treatment. According to the tensile tests carried out at $1098 \mathrm{~K}$, ultra-fine-grained Ti-3Al-2.5V exhibited very large elongations of more than $9000 \%$.

(Received October 21, 2005; Accepted December 12, 2005)

Keywords: titanium, hydrogen treatment, ultra-fine grain, tensile properties, martensite

\section{1. 緒論}

金属材料の高性能化, とりわけ延性や靶性をあまり犠牲に することなく高強度化する手段として結晶粒の微細化(微細 粒化) が挙げられ，その一つに水素処理法1,2)がある。いわゆ る水素吸蔵-溶体化・マルテンサイト化(焼入れ)-熱間圧延脱水素処理である. この処理によって $\alpha$ (稠密六方晶 $)+\beta$ (体 心立方晶) 2 相型 $\mathrm{Ti}-6 \mathrm{Al}-4 \mathrm{~V}$ 合金の結晶粒径は $0.3 \sim 0.5 \mu \mathrm{m}$ となり, 耐力はホールペッチの式に従って格段に向上し, ま た極めて優れた超塑性を示すことがこれまでの研究3-5)でわ かっている. しかしながら, この微細粒化に極めて有効な水 素処理法を他のチタン系材料に適用した例はない. そこで本

*1 福山大学大学院生, 現在 : 日本ホイスト侏 (Graduate Student, Fukuyama University, Present address: Nippon Hoist Co., Ltd.)

*2 福山大学大学院生 (Graduate Student, Fukuyama University)

*3 福山大学大学院生, 現在 : 秼システムサービス (Graduate Student, Fukuyama University, Present address: System Service Co., Ltd.)
研究6)では,この水素処理の適用範囲を拡大することを目的 に, Ti-6Al-4V 合金と同じ 2 相型の Ti-Al-V 系合金, Ti$\mathrm{Fe}-\mathrm{O}$ 系合金, さらに $\alpha$ 単相型の純チタンに本処理の適用を 試みた。

\section{2. 実 験 方 法}

\section{1 供試素材}

供試素材には $\alpha+\beta 2$ 相型の $\mathrm{Ti}-3 \mathrm{Al}-2.5 \mathrm{~V}$ 合金 (以下 $\mathrm{Ti}-$ $3 \mathrm{Al}-2.5 \mathrm{~V}$ と記す), $\mathrm{Ti}-1 \mathrm{Fe}-0.35 \mathrm{O}$ 合金 $(\mathrm{Ti}-1 \mathrm{Fe}-0.35 \mathrm{O})$, そ して $\alpha$ 単相型の工業用純チタン JIS 2 種材 $(\mathrm{CP}-\mathrm{Ti})$ の熱間押 出材を用いた。

\section{2 水素吸蔵処理亡 $\beta$ 変態点の測定}

供試素材より, 厚さ $25 \mathrm{~mm} \times$ 幅 $25 \mathrm{~mm} \times$ 長さ $50 \mathrm{~mm}$ の 試料を切り出し, これを用いて所定の水素吸蔵量の材料を得 るための水素吸蔵条件をまず調べた. 目標とする水素吸蔵量 は, 前報 ${ }^{4)}$ の $\mathrm{Ti}-6 \mathrm{Al}-4 \mathrm{~V}$ 合金が最も微細粒化する吸蔵量 0.5 mass \% (以下，単に\%と記す) を参考とし，その付近の $0.3 〜$ 
1.0\%とした。試料を水素吸蔵炬に挿入，アルゴンガス気流 中にて加熱, $1073 \mathrm{~K}$ に達した時点で水素ガス気流に置換, 保持した.この時の保持時間を変化させて, 種々の吸蔵量を 有する試料の作製を試みた。 保持後は再びアルゴンガス気流 中にて冷却した。 なお, 水素吸蔵量は処理前後の試料の重量 を測定して求めた.

また, 水素は $\beta$ 相安定化元素であるが故に, その吸蔵量 と共に $\beta$ 変態点は低下する.よって水素処理を行う前に, 水素を吸蔵した各チタン材の $\beta$ 変態点を求める必要があ る. そこで水素吸蔵量の異なる試料(厚さ $12 \mathrm{~mm} \times$ 幅 12 $\mathrm{mm} \times$ 長さ $25 \mathrm{~mm}$ ) を上述の方法で準備し, それを 878〜 $1233 \mathrm{~K}$ に大気中にて加熱, $1.8 \mathrm{ks}$ 間保持した後, 水冷した (このときの保持時間は, 材料に内部における水素の均一分 散化に十分な時間であることが予備実験において確認されて いる). そして光学顕微鏡にて組織を観察し， $\alpha$ 相やマルテ ンサイト $\left(\alpha^{\prime}\right)$ 相の分布状態などから打抢よその $\beta$ 変態点を求 めた.

\section{3 水素処理}

各供試素材より厚さ $25 \mathrm{~mm} \times$ 幅 $25 \mathrm{~mm} \times$ 長さ $50 \mathrm{~mm}$ の 試料を切り出し, これに水素処理を行った. 水素処理の模式 的熱履歴線図を Fig. 1 に示す。このように水素処理は(1)水 素吸蔵処理, (2)溶体化· $\alpha^{\prime}$ 化(焼入れ), (3)熱間圧延, (4)脱水 素処理の 4 工程からなっており, 各工程の最適条件, 特に 水素吸蔵量抢よび熱間圧延条件を求めることによって各材料 の微細粒化を試みる. その詳細は次の通りである.

\subsection{1 最適水素吸蔵量の把握}

試料に所定の量の水素を吸蔵させるために, 2.2 項と同じ 処理工程にて水素吸蔵処理を行った. この処理によって得ら れた水素吸蔵量の異なる 4 種類の試料 ( $0.3 \%$ 材, $0.5 \%$ 材, $0.7 \%$ 材， $1 \%$ 材) および比較のために準備した水素吸蔵無し 材 $\left(0 \%\right.$ 材) に溶体化 $\cdot \alpha^{\prime}$ 化, 熱間圧延, 脱水素処理を施し た.なお，このときの溶体化・ $\alpha^{\prime}$ 化は，いずれも水素を吸蔵 した試料の $\beta$ 変態点より $100 \mathrm{~K}$ 高い温度で, 大気中にて 3.6 $\mathrm{ks}$ 間保持 (この条件下での試料の酸素污染層の厚さは 0.1 $\mathrm{mm}^{7}$ ) 以下と思われる) した後に水冷, 熱間圧延は $\beta$ 変態点

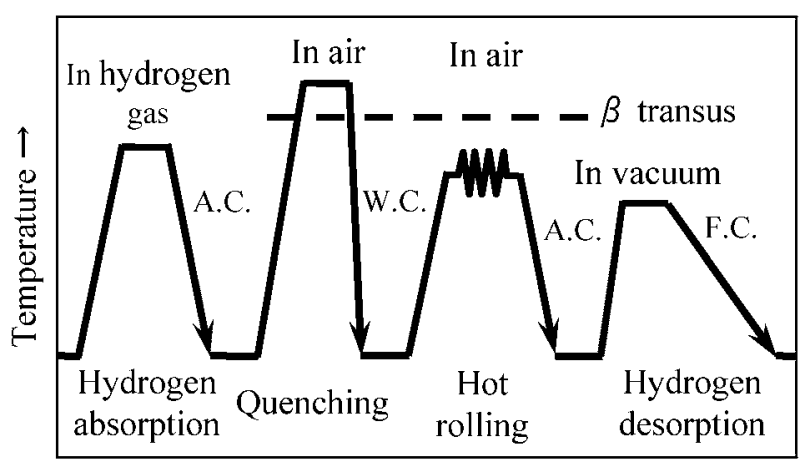

Time $\rightarrow$

A.C.: Air cooling W.C.: Water cooling

F.C.: Furnace cooling

Fig. 1 Schematic diagram of heat patterns of hydrogen treatment.
より $100 \mathrm{~K}$ 低い温度で, 圧下率 $80 \%$ で行った. 圧延後の試 験片の表面酸化被膜を除去した後, 最終工程の脱水素処理 を，いずれも真空中で温度 $873 \mathrm{~K}$ に加熱, $3.6 \mathrm{ks}$ 間保持 後, 炉冷して行った. このことにより水素吸蔵量の変化のみ での組織の変化が把握できるようにした．そして微細粒化に 対して最適な水素吸蔵量を後述する金属組織観察の結果より 求めた. また, 水素を吸蔵した各試料のマルテンサイト組織 の形態を把握するために, 水素吸蔵-溶体化・ $\alpha^{\prime}$ 化後の組織 も観察した.

\subsection{2 熱間圧延条件の把握}

2.3.1 項で求めた最適な水素量を吸蔵させ, 溶体化 $\cdot \alpha^{\prime}$ 化 した試料から厚さ $7 \mathrm{~mm} \times$ 幅 $7 \mathrm{~mm} \times$ 長さ $25 \mathrm{~mm}$ の圧延用 試料を切り出し, これに熱間圧延を施した. この時, 水素処 理後の組織に及ぼす圧延温度の影響を調べるために, 圧下率 を一定 $(80 \%)$ とし, 温度を $\beta$ 変態点より $50 \mathrm{~K}$ 高い温度か ら, 圧延時に割れが生じるまでの低い温度にまで変化させて 行った. また, 同様に圧下率の影響を調べるために, 圧延温 度を一定 $(\beta$ 変態点より $100 \mathrm{~K}$ 低い温度 $)$ とし, 累積圧下率 （以下，単に圧下率と記す）を変化させて圧延を行った．そし てこれらの試料の酸化皮膜を除去した後, 脱水素処理 (真空 中, 温度 $873 \mathrm{~K}$, 保持時間 $3.6 \mathrm{ks}$ ) を施し, その後の組織観 察結果より, 最適圧延条件を求めた.

\section{4 金属組織観察}

2.3 節の処理によって得られた種々の試料の組織観察は, 光学顕微鏡 (光顕), 走査型電子顕微鏡 $(\mathrm{SEM})$ を用いて行っ た. 組織観察用試料は, 観察面を鏡面研磨し, その面を硝酸 $6 \%$, 沸酸 $3 \%$, 水 $91 \%$ の割合の混合液にて腐食させて作製 した.

\section{5 室温および超塑性引張試験}

水素処理材の室温での引張特性を調べるために, 試験片平 行部厚さ $1.6 \mathrm{~mm} \times$ 幅 $5 \mathrm{~mm} \times$ 長さ $20 \mathrm{~mm}$ の板状の引張試験 片 (JIS 14B 号)を処理材より切り出した. そして, 初期ひず 久速度 $2.5 \times 10^{-3} \mathrm{~s}^{-1}$ にて引張試験を行った. 同様に, 平行 部厚さ $5 \mathrm{~mm} \times$ 幅 $5 \mathrm{~mm} \times$ 長さ $4 \mathrm{~mm}$, 肩部半径 $10 \mathrm{~mm}$ の板 状の引張試験片を切り出し, 真空中 $\left(10^{-3} \mathrm{~Pa}\right.$ 以下)にて温度 および初期歪み速度を変化させて超塑性引張試験を行い, 水 素処理材の最大超塑性伸びを求めた.

\section{3. 実 験 結 果}

\section{1 水素吸蔵量に及ぼす保持時間の影響}

各試料を水素吸蔵炉に挿入，アルゴンガス気流中にて加熱, $1073 \mathrm{~K}$ に達した時点で水素ガス気流に置換, 保持した.こ の時の保持時間を変化させて, 種々の吸蔵量を有する試料の 作製を試みた結果，Table 1 に示す保持時間にすることによ って $0.3 \sim 1.0 \%$ の水素吸蔵量を有する試料が得られた。この 結果を基に，水素吸蔵量の異なる試料を作製した。なお，同 じ水素吸蔵量の試料を得る場合でも，高合金材料ほど保持時 間は長くなる傾向があることがわかった。 


\section{2 水素吸蔵材の $\beta$ 変態点}

所定量の水素を吸蔵させた試料を種々の温度に加熱, 保持 し, 水冷した後の組織を観察して求めた $\beta$ 変態点を Table 2 に示す. いずれも水素吸蔵量増加とともに $\beta$ 変態点は低下 する傾向が確認された.

\section{3 水素処理後の組織に及ぼす水素吸蔵量の影響}

水素吸蔵量を $0 \sim 1.0 \%$ に変化させた試料に, 通常の水素

Table 1 Hydrogen absorption condition (holding time (ks) at $1073 \mathrm{~K}$ in $\mathrm{H}_{2}$ ) of each material.

Specimen size: $25 \mathrm{~mm} \times 25 \mathrm{~mm} \times 50 \mathrm{~mm}$

\begin{tabular}{lllll}
\hline $\begin{array}{c}\text { Hydrogen } \\
\text { content }\end{array}$ & $0.3 \%$ & $0.5 \%$ & $0.7 \%$ & $1.0 \%$ \\
\hline $\mathrm{Ti}-3 \mathrm{Al}-2.5 \mathrm{~V}$ & 0.21 & 0.54 & 1.08 & 3.90 \\
\hline $\mathrm{Ti}-1 \mathrm{Fe}-0.35 \mathrm{O}$ & 0.18 & 0.42 & 0.75 & 1.56 \\
\hline $\mathrm{CP}-\mathrm{Ti}$ & 0.15 & 0.36 & 0.66 & 1.32 \\
\hline
\end{tabular}

処理条件にて溶体化· $\alpha^{\prime}$ 化, 熱間圧延, 脱水素処理を施した 後の組織を光顕で観察した結果を Fig. 2 に示す.

まず Ti-3Al-2.5Vの 0\%材，いわゆる水素吸蔵無しでは 結晶粒径は 3〜 $5 \mu \mathrm{m}$ 程度であったが (Fig. 2(a)), 0.3\%材, $0.5 \%$ 材および $0.7 \%$ 材についてはいずれも均一な微細粒組織 となることがわかった(Fig. 2(b)，(c)，(d)).1\%材について はやや均一性に欠けた微細粒組織となっていた（Fig. $2(\mathrm{e}))$. 以上のことから, $\mathrm{Ti}-3 \mathrm{Al}-2.5 \mathrm{~V}$ の最適な水素吸蔵量 は $0.3 \sim 0.7 \%$ である.

次に $\mathrm{Ti}-1 \mathrm{Fe}-0.35 \mathrm{O}$ であるが，水素吸蔵量 $0 \%$ では微細粒

Table $2 \beta$ transus temperature $(\mathrm{K})$ of hydrogen absorbed materials.

\begin{tabular}{lccccc}
\hline Hydrogen content & $0 \%$ & $0.3 \%$ & $0.5 \%$ & $0.7 \%$ & $1.0 \%$ \\
\hline $\mathrm{Ti}-3 \mathrm{Al}-2.5 \mathrm{~V}$ & 1213 & 1043 & 953 & 863 & 743 \\
\hline $\mathrm{Ti}-1 \mathrm{Fe}-0.35 \mathrm{O}$ & 1223 & 1058 & 963 & 873 & 753 \\
\hline $\mathrm{CP}-\mathrm{Ti}$ & 1183 & 1018 & 923 & 833 & 713 \\
\hline
\end{tabular}
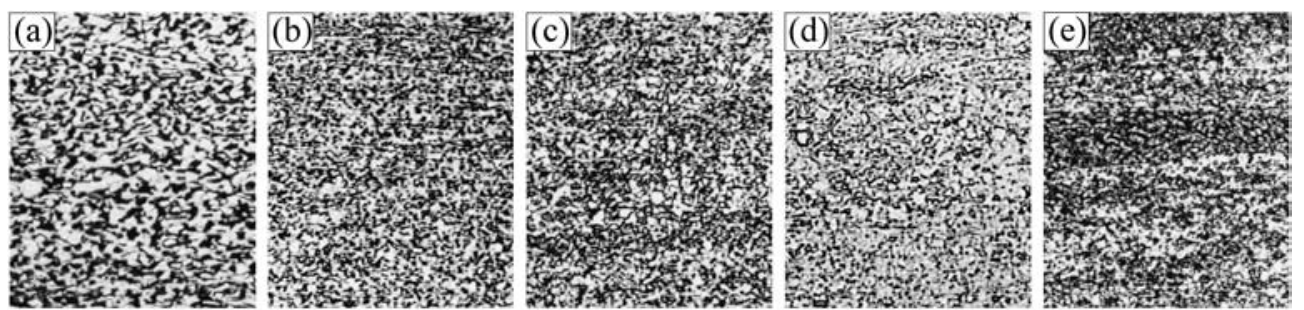

\section{【Ti-3Al-2.5V】}
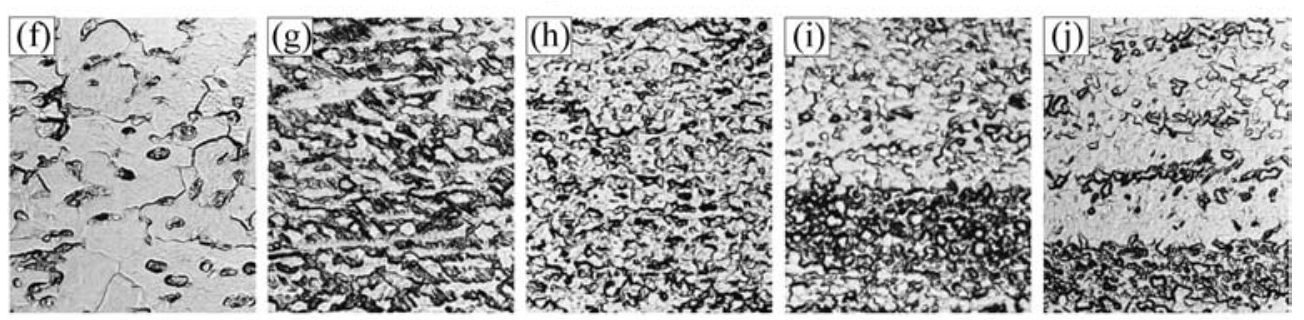

【Ti-1Fe-0.35O】
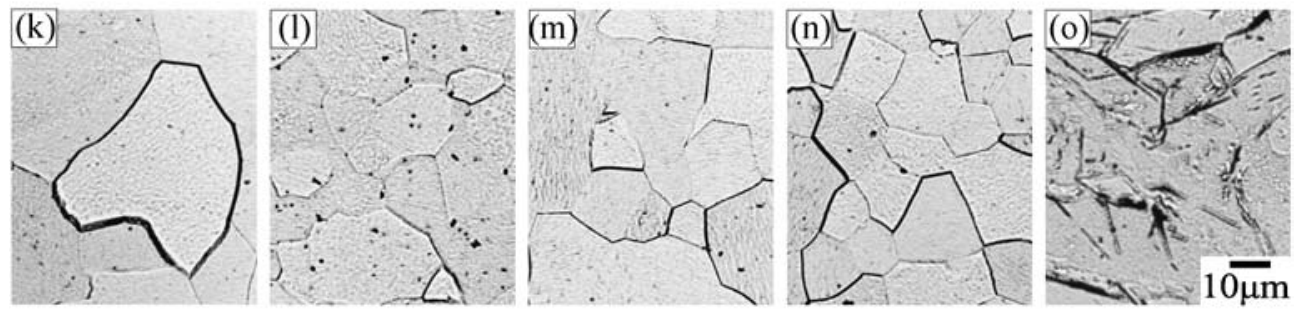

\section{【CP-Ti】}

$0 \%[\mathrm{H}]$

$0.3 \%$

$0.5 \%$

$0.7 \%$

$1.0 \%$

Hydrogen content

[Treatment conditions ]

Quenching temp. : 100K above $\beta$ transus

Hot rolling temp. : $100 \mathrm{~K}$ below $\beta$ transus

Reduction : $80 \%$

Hydrogen desorption temp. : 873K

Fig. 2 Influence of hydrogen content on microstructure in hydrogen treated and $80 \%$ hot rolled state. 
化は確認されなかった(Fig. 2(f))。0.3\%材においても，0\% 材ほどではないが，やや粗大な $\alpha$ 粒が確認されたが (Fig. $2(\mathrm{~g})), 0.5 \%$ 材については均一な微細粒組織となることがわ かった (Fig. 2(h)). 0.7\%材および 1\%材においてはやや均 一性に欠けた組織となっていた (Fig. 2(i), (j)). 以上のこと から, $\mathrm{Ti}-1 \mathrm{Fe}-0.35 \mathrm{O}$ の水素処理に打ける最適な水素吸蔵量 は $0.5 \%$ である.

$\mathrm{Ti}-3 \mathrm{Al}-2.5 \mathrm{~V}$ および $\mathrm{Ti}-1 \mathrm{Fe}-0.35 \mathrm{O}$ 共に水素吸蔵量が多く なると, 組織が不均一になる傾向がある.これは局部的に水 素濃度の高い領域が存在することが推測され, そこで共析 (共析点 : 1.3 mass \%) が生じたことが一因として考えられる.

CP-Tiについてはいずれの水素吸蔵量に掞いても微細粒 組織は得られなかった (Fig. $2(\mathrm{k}) 〜(\mathrm{o}))$.

\section{4 水素吸蔵後およびマルテンサイト $\left(\alpha^{\prime}\right)$ 化後の組織}

$\mathrm{Ti}-3 \mathrm{Al}-2.5 \mathrm{~V}$ および CP-Ti の水素吸蔵 $(0.5 \%)$ 後, $\alpha^{\prime}$ 化後 の組織を Fig. 3 に示す. 水素吸蔵前の Ti-3Al-2.5V は一面 に等軸組織が観察されたが (Fig. $3(\mathrm{a})$ ), 水素吸蔵後は試料 表層部と内部とで異なる様相を示していた，表層部では一面 に針状組織となっているのに対し, 内部では吸蔵前の組織を 維持して抢り，このことは表層部と内部とで水素濃度に差が あることを示唆している(Fig. 3(b)，(c))。しかしながら， $\alpha^{\prime}$ 化後の組織は表層部抢よび内部いずれも均一で, かつ微細
な針状組織となっていた (Fig. 6(d)，(e)).なおここには 示さないが， $\mathrm{Ti}-1 \mathrm{Fe}-0.35 \mathrm{O}$ に打いても同様な組織が確認さ れている.

水素処理によって微細粒化しなかった CP-Ti についても 同様な傾向が確認されたが，注目すべきことは，針状組織が $\mathrm{Ti}-3 \mathrm{Al}-2.5 \mathrm{~V}$ と比較して極めて粗大であるということであ る(Fig. 3(g), (i), (j)).

\section{5 水素処理後の組織に及ぼす圧延条件の影響}

\subsection{1 圧延温度の影響}

水素処理後の組織に及ぼす圧延温度の影響を Fig. 4 に示 す. Ti-3Al-2.5V および Ti-1Fe-0.35O については, $\beta$ 変態 点より $50 \mathrm{~K}$ 高い温度で圧延して水素処理を行った場合, い ずれの材料も所々に板状 $\alpha$ 相と思われる組織が現れ，この 温度領域での圧延では等軸微細粒組織は得られなかった (Fig. 4 (a), (e)). しかし, $\beta$ 変態点より低い温度, 具体的 には Ti-3Al-2.5V: 753〜903 K, Ti-1Fe-0.35O: 713〜 763 K にて圧延を行った場合，均一な等軸微細粒組織が得られるこ とがわかった (Fig. 4(b)〜 (d)，(f)〜 (h)).これよりさらに 低い温度での圧延は, 試料に割れが生じ, 不可能であった。

なお，ここには示さないが，CP-Tiにおいては圧延温度 を $\beta$ 変態点以下にて行うことで若干の微細粒化の傾向を示 したが，その粒径は約 $10 \mu \mathrm{m}$ 程度であり，本研究において

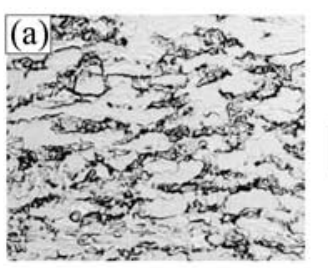

【Ti-3Al-2.5V】

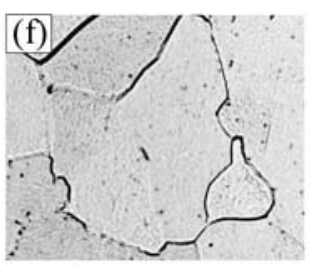

【CP-Ti】

Before hydrogen absorption
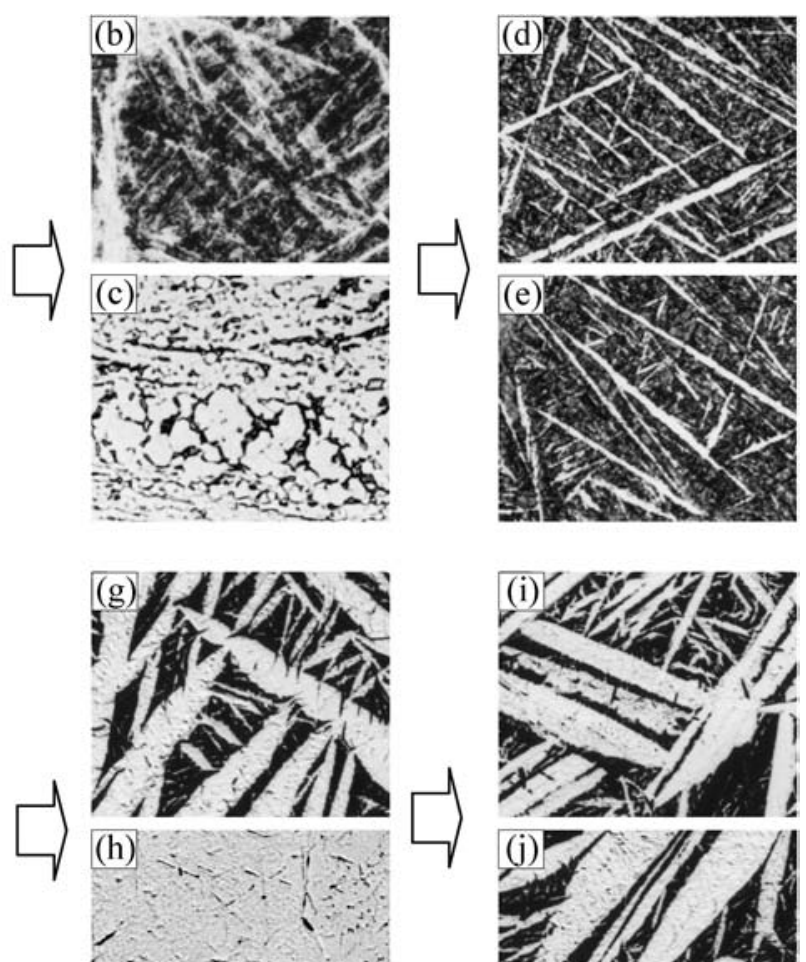

(h)
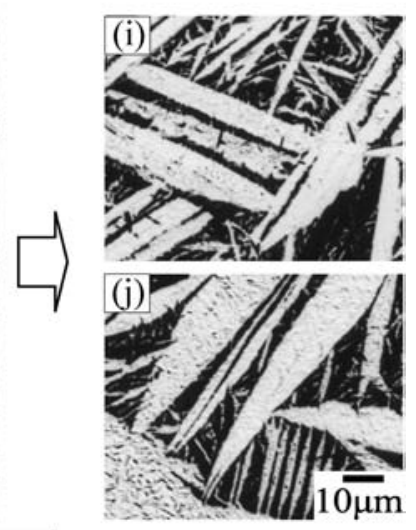

After hydrogen absorption (Hydrogen content : $0.5 \%$ )
After quenching

Fig. 3 Microstructure of Ti-3Al-2.5V( (b) and (c)) and CP-Ti ( $(\mathrm{g})$ and (h)) after hydrogen absorption, and those of Ti-3Al-2.5V $((d)$ and $(\mathrm{e}))$ and $\mathrm{CP}-\mathrm{Ti}((\mathrm{i})$ and $(\mathrm{j}))$ after quenching from $\beta$ single phase region following the hydrogen absorption. 


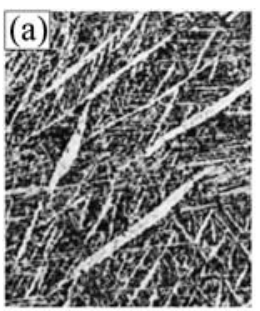

(a) $1003 \mathrm{~K}$

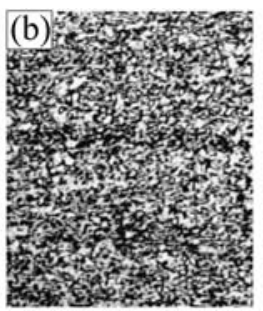

(b) $903 \mathrm{~K}$

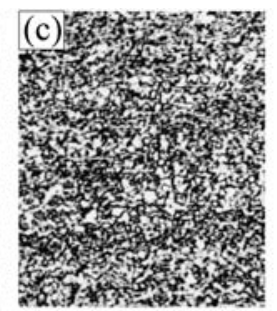

(c) $853 \mathrm{~K}$

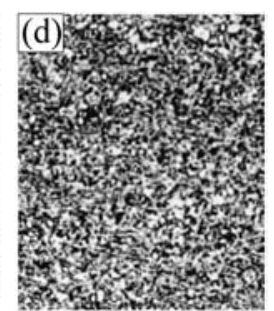

(d) $753 \mathrm{~K}$

【Ti-3Al-2.5V: Reduction in thickness : 80\%】

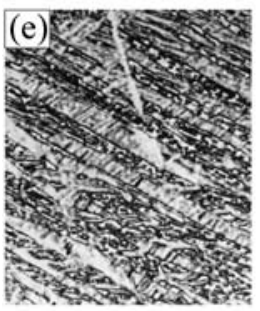

(e) $1013 \mathrm{~K}$

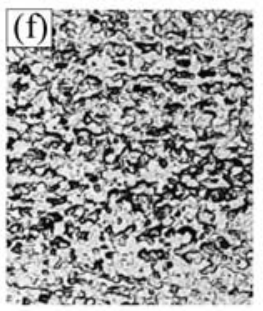

(f) $863 \mathrm{~K}$

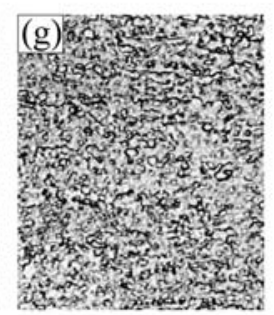

(g) $763 \mathrm{~K}$

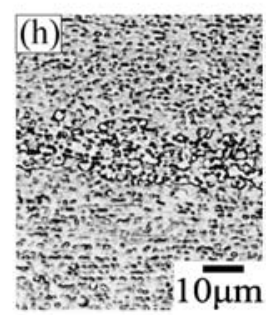

(h) $713 \mathrm{~K}$

【Ti-1Fe-0.35O : Reduction in thickness : $80 \%$ 】

[Treatment conditions ]

Hydrogen absorption content : $0.5 \%$

Quenching temp. : 100K above $\beta$ transus

Hydrogen desorption temp. : $873 \mathrm{~K}$

Fig. 4 Influence of rolling temperature $(80 \%$ as reduction in thickness) on microstructure after hydrogen treatment $(0.5 \%[\mathrm{H}])$.

は水素処理による微細粒化は達成できなかった。

\subsection{2 圧下率の影響}

Ti-3Al-2.5V の水素処理後の組織に及ぼす圧下率の影響 をFig. 5 に示す。圧下率 40\%では均一性に欠け，また一部 に針状組織が残留している(Fig. 5(a))。しかしながら圧下 率を $60 \%$ 以上とした場合, 均一な等軸微細粒組織となるこ とがわかった(Fig. 5(b)，(c))。この結果から，Ti-3Al$2.5 \mathrm{~V}$ の圧延工程に打忊圧下率は $60 \%$ 以上が必要である.

Ti-1Fe-0.35O については 80\%以上とした場合，Ti-3Al$2.5 \mathrm{~V}$ と同様, 均一な等軸微細粒組織となることがわかった (Fig. 5(f)).

\section{6 超微細粒組織の SEM 観察}

上記の実験において得られた最適水素処理条件ををとめた ものを Table 3 に，また，その条件で処理した Ti-3Al$2.5 \mathrm{~V}, \mathrm{Ti}-1 \mathrm{Fe}-0.35 \mathrm{O}$ の組織を SEM にて観察した結果を Fig. 6 に示す. Ti-3Al-2.5V の結晶粒径は $0.5 \sim 1 \mu \mathrm{m}, \mathrm{Ti}-$ $1 \mathrm{Fe}-0.35 \mathrm{O}$ は約 $1 \mu \mathrm{m}$ のいわゆる超微細粒組織となっている ことがわかった。

\section{7 室温および超塑性引張特性}

最適水素処理条件にて処理を行い，超微細粒化した Ti$3 \mathrm{Al}-2.5 \mathrm{~V}$ (結晶粒径 $0.5 \sim 1 \mu \mathrm{m}$, 超微細 $\mathrm{Ti}-3 \mathrm{Al}-2.5 \mathrm{~V}$ と記 す), 比較として水素吸蔵無しで超微細 $\mathrm{Ti}-3 \mathrm{Al}-2.5 \mathrm{~V}$ と同じ 熱履歴の $\mathrm{Ti}-3 \mathrm{Al}-2.5 \mathrm{~V}(3 \sim 5 \mu \mathrm{m}$, 粗粒 $\mathrm{Ti}-3 \mathrm{Al}-2.5 \mathrm{~V})$ の室温 に抢ける公称応力ーひずみ線図を Fig. 7 に示す。粗粒 $\mathrm{Ti}-$

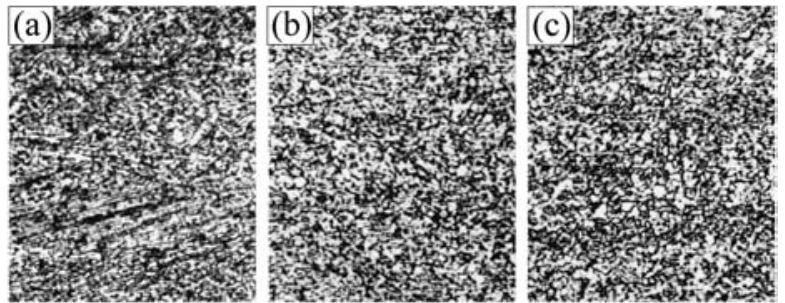

【Ti-3Al-2.5V : Hot rolling temp. : 853K】

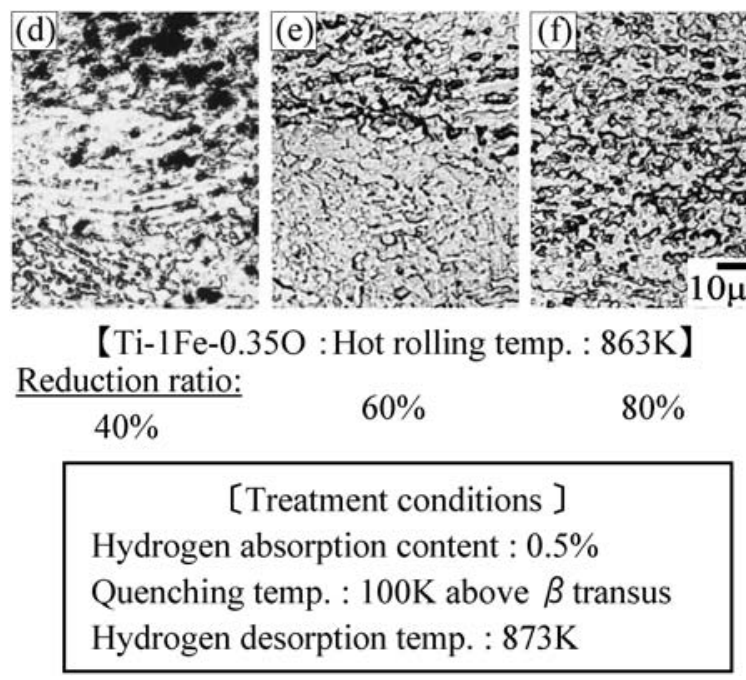

Fig. 5 Influence of reduction in thickness ( $100 \mathrm{~K}$ below $\beta$ transus as rolling temperature) on microstructure after hydrogen treatment. 
Table 3 Optimum hydrogen treatment condition of each material.

\begin{tabular}{|c|c|c|c|c|c|}
\hline \multirow{2}{*}{ Process } & \multirow{2}{*}{$\begin{array}{c}\text { Hydorgen } \\
\text { abosorption } \\
\text { content }(\%)\end{array}$} & \multirow{2}{*}{$\begin{array}{l}\text { Quenching } \\
\text { Temp }\end{array}$} & \multicolumn{2}{|c|}{ Hot rolling } & \multirow{2}{*}{$\begin{array}{l}\text { Hydrogen } \\
\text { desorption } \\
\text { Temp..(K) }\end{array}$} \\
\hline & & & Temp (K) & $\begin{array}{c}\text { Reduction } \\
(\%)\end{array}$ & \\
\hline $\mathrm{Ti}-3 \mathrm{Al}-2.5 \mathrm{~V}$ & $0.3 \sim 0.7$ & \multirow{2}{*}{$\begin{array}{c}100 \mathrm{~K} \text { above } \\
\beta \text { transus }\end{array}$} & $753 \sim 903$ & $>60$ & \multirow{2}{*}{873} \\
\hline $\mathrm{Ti}-1 \mathrm{Fe}-0.350$ & 0.5 & & $713 \sim 763$ & $>80$ & \\
\hline $\mathrm{CP}-\mathrm{Ti}$ & & & - & & \\
\hline
\end{tabular}

3Al-2.5V は通常の典型的な引張曲線となっており, 塑性変 形域ではひずみの増加と共に応力も増加, 応力が最大を示し た後に減少して破断に至っている. 超微細 Ti-3Al-2.5V に ついても塑性変形域ではひずみの増加と共に応力も増加す る.しかし，その増加割合は粗粒 Ti-3Al-2.5V ほどではな い. そして最大応力を示した後に破断している. $0.2 \%$ 耐力 に注目すると，粗粒 Ti-3Al-2.5V が $626 \mathrm{MPa}$ であるのに対 して超微細 Ti-3Al-2.5V は $746 \mathrm{MPa}$ と, 超微細粒化と共に

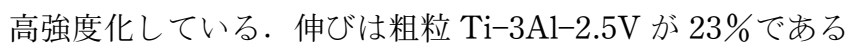
のに対し, 超微細 Ti-3Al-2.5V は 16\% と, やや低下する傾 向を示した. 同じく超微細 $\mathrm{Ti}-1 \mathrm{Fe}-0.35 \mathrm{O}(1 \mu \mathrm{m})$ について も, 上述の Ti-3Al-2.5V と同様に超微細粒化と共に高強度 化していることがわかる(Fig. 7(b)).

真空中にて温度 $1123 \mathrm{~K}$, 初期歪み速度 $2 \times 10^{-3} \mathrm{~s}^{-1}$ の条 件にて超塑性引張試験を行った結果, 粗粒 Ti-3Al-2.5V で は約 3000\%の超塑性伸びだったのに対し, 超微細 Ti-3Al$2.5 \mathrm{~V}$ は，9000\%以上という極めて大きな超塑性伸びを示し た Fig. 8). 今後, この優れた超塑性の応用が期待される.

\section{4. 考察}

\section{1 超微細粒組織と針状マルテンサイト組織}

本研究の結果より, $\alpha+\beta 2$ 相型の $\mathrm{Ti}-3 \mathrm{Al}-2.5 \mathrm{~V}$ および $\mathrm{Ti}-1 \mathrm{Fe}-0.35 \mathrm{O}$ においては, 水素処理によって超微細粒化が 達成された。しかしながら， $\alpha$ 単相型の工業用純チタン JIS 2 種 (純 $\mathrm{Ti}$ ) については一切その傾向を示さなかった。 その 要因は単相か多相かの違いがあるとはいえ, その理由だけで は決して十分とは言えない。ここで注目すべき点として挙げ られるのが, 水素吸蔵-溶体化・マルテンサイト $\left(\alpha^{\prime}\right)$ 化後に 生じる微細な針状マルテンサイトの存在である. 種々のチタ ン系材料の $\beta$ 単相領域からの急冷金属組織は, その材料に 含まれる $\beta$ 相安定化元素によって大きく異なることがこれ までの多くの研究結果 ${ }^{8-10)}$ の中で明らかになっている. その 中で藤井ら ${ }^{11)}$ は， $\beta$ 相安定化元素をより多く添加すること で，チタン合金の急冷組織は板状から針状組織へと遷移する ことを見いだしている，その要因として， $\beta$ 安定度の低い合 金では水冷でも拡散を伴った変態をするが， $\beta$ 安定度が高ま るにつれ，それは無拡散マルテンサイト変態へと変化するた めと考察している. 各チタン系材料に水素を $0.5 \%$ 程吸蔵さ せ, 溶体化・ $\alpha^{\prime}$ 化処理した後の組織および水素処理後の組織 を光顕および SEM で観察したものを再度 Fig. 9 に示す. 超 微細粒化を示した Ti-6 $\left.\mathrm{Al}-4 \mathrm{~V}^{4}\right), \mathrm{Ti}-3 \mathrm{Al}-2.5 \mathrm{~V}, \mathrm{Ti}-1 \mathrm{Fe}-$ 0.350 , いわゆる $\beta$ 相安定化元素を含んだ合金においてはい ずれも極めて微細な針状組織を呈しているのに対し, CP-Ti は粗大な針状組織となっており，この結果はこの藤井らのも のと一致していると考えられる. その組織を熱間圧延, 脱水 素処理を行って得られた組織に注目すると, Ti-6Al-4V 合

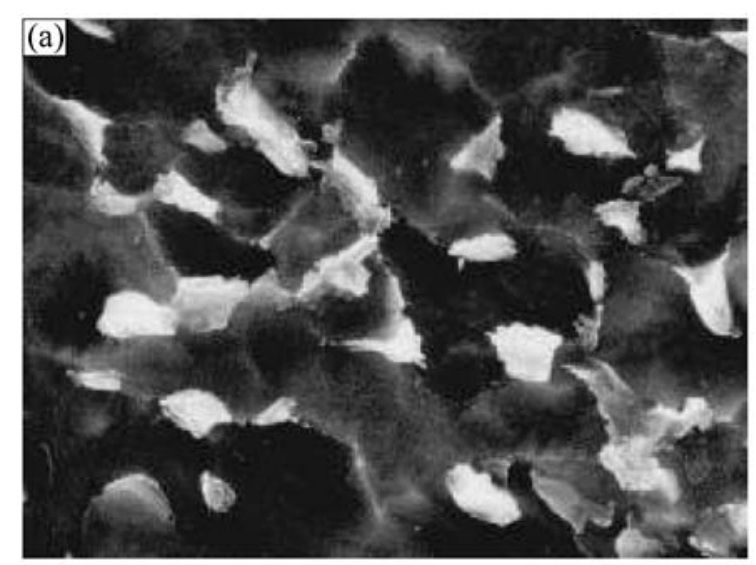

[Treatment conditions ]

Hydrogen absorption content : $0.5 \%$ Quenching temp. : 1053K

Hot rolling temp. : $753 \mathrm{~K}$

Reduction : $80 \%$

Hydrogen desorption temp. : $873 \mathrm{~K}$

(a) Ultra-fine-grained Ti-3Al-2.5V

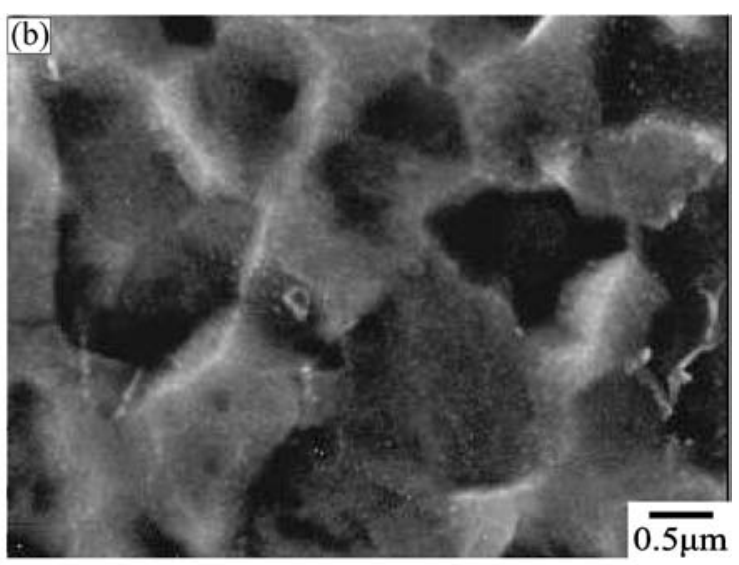

[ Treatment conditions ] Hydrogen absorption content : $0.5 \%$ Quenching temp. : 1063K Hot rolling temp. : $763 \mathrm{~K}$ Reduction : $80 \%$

Hydrogen desorption temp. : $873 \mathrm{~K}$

(b) Ultra-fine-grained Ti-1Fe- $0.35 \mathrm{O}$

Fig. 6 SEM photographs of ultra-fine-grained material. 
金は $0.3 \sim 0.5 \mu \mathrm{m}$ ，以下 $\mathrm{Ti}-3 \mathrm{Al}-2.5 \mathrm{~V}: 0.5 \sim 1 \mu \mathrm{m}$, Ti-1Fe0.35O: 約 $1 \mu \mathrm{m}, \mathrm{CP}-\mathrm{Ti}: 10 \mu \mathrm{m}$ と, 合金内の $\beta$ 相安定化元素 が多くなるにつれ，水素処理による超微細粒化はより顕著に

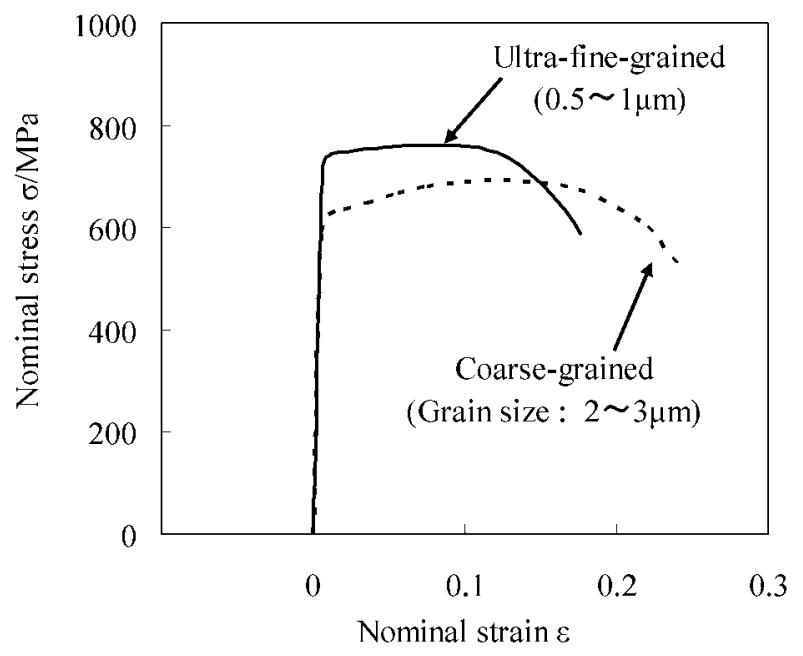

(a) Ti-3Al-2.5V

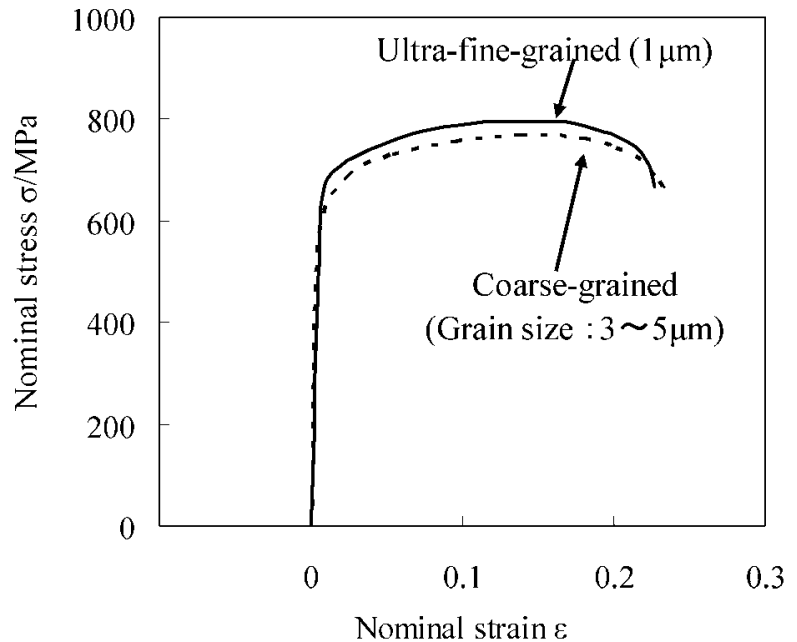

(b) Ti-1 Fe-0.35O

Fig. 7 Comparison of nominal stress-nominal strain curves of ultra-fine-grained materials ( $\mathrm{Ti}-3 \mathrm{Al}-2.5 \mathrm{~V}$ and $\mathrm{Ti}-1 \mathrm{Fe}-0.35 \mathrm{O})$ and the coarse-grained materials.
表れていることがわかる. よって, $\alpha+\beta$ 型合金で $\beta$ 相の安 定度が高いほど， $\beta$ 単相域からの急冷により微細な針状マル テンサイトが多数現れ, さらに水素も $\beta$ 相安定化元素であ るので，その傾向はさらに強くなったものと考えられる.

次に，この微細な針状マルテンサイトと等軸微細粒組織と の関係を考察する. 水素処理の微細粒化原理の基本は「析出 物 (水素化物)を起点とした微細な再結晶粒を作る」12)ことに ある.よって，この針状マルテンサイトとこの原理との関係 を明確にする必要がある。これについては針状マルテンサイ トおよびその周辺には高密度の転位領域が形成されることが 過去の研究1)で明らかにされている．このことから，微細な 針状マルテンサイトが多く生成させることにより，より多く の高密度転位領域の導入が可能となる. そして次の 2 相温 度領域での熱間圧延工程では $\alpha$ 相が析出し，この $\alpha$ 相が圧 延の際，転位発生の起点として機能することで転位はさらに 増加するものと考えられる ${ }^{2)}$. 最終工程の脱水素処理中では 前工程にて生成した転位領域から水素化物が析出して核生成 と成長が生じ，結果として微細粒化が達成されると考えられ る.このような観点から, 水素処理による超微細粒化には微 細な針状マルテンサイト組織の生成による高密度転位領域が 必須であり，そのためには合金中に含まれる $\beta$ 相安定化元 素が重要であることが本研究により示された.

\section{5. 結 論}

水素処理によって $\alpha+\beta 2$ 相型の $\mathrm{Ti}-3 \mathrm{Al}-2.5 \mathrm{~V}$ 合金および $\mathrm{Ti}-1 \mathrm{Fe}-0.35 \mathrm{O}$ 合金, $\alpha$ 単相型の工業用純チタン JIS 2 種材 の超微細粒化のための条件を探索し，さらに得られた超微細 組織を有する材料の室温打よび超塑性引張試験を行ってその 特性を明らかにした。これらの結果を総括すると以下のよう になる。

(1) 微細粒化のための最適水素吸蔵量は, Ti-3Al-2.5V 合金は $0.3 \sim 0.7 \%, \mathrm{Ti}-1 \mathrm{Fe}-0.35 \mathrm{O}$ 合金は $0.5 \%$ である. 吸蔵 量が少ない場合は微細粒化の効果は少なく，また逆に多くな ると，やや均一性に欠けた微細粒組織となる.

（2）溶体化・ $\alpha^{\prime}$ 化は水素の均一化に重要な役割を果たす. 水素吸蔵後, 試験片表層部と内部とで水素濃度に差があるこ

\section{C}

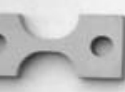

Before testing

\section{c}

Coarse-grained : Superplastic elongation : $3000 \%$

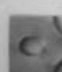

Ultra-fine-grained : over $9000 \%$
Temperature : $1123 \mathrm{~K}$

Initial strain rate : $2 \times 10^{-3} \mathrm{~S}^{-1}$

Fig. 8 Comparison of superplastic elongation of ultra-fine-grained Ti-3Al-2.5V and the coarse-grained material. 

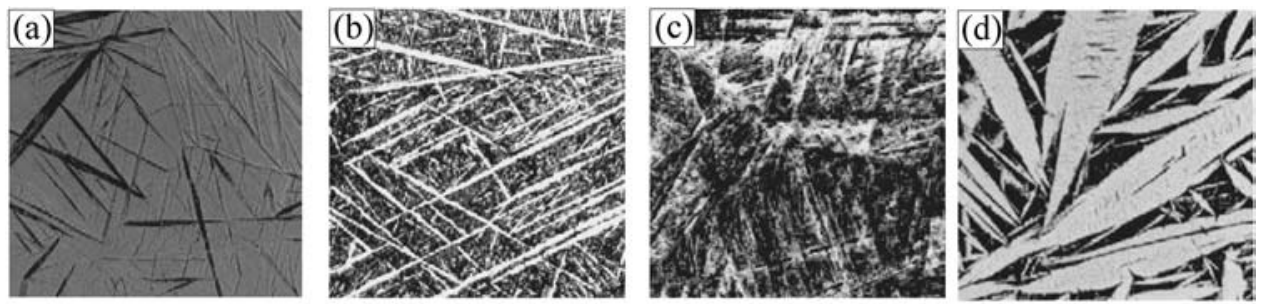

After quenching
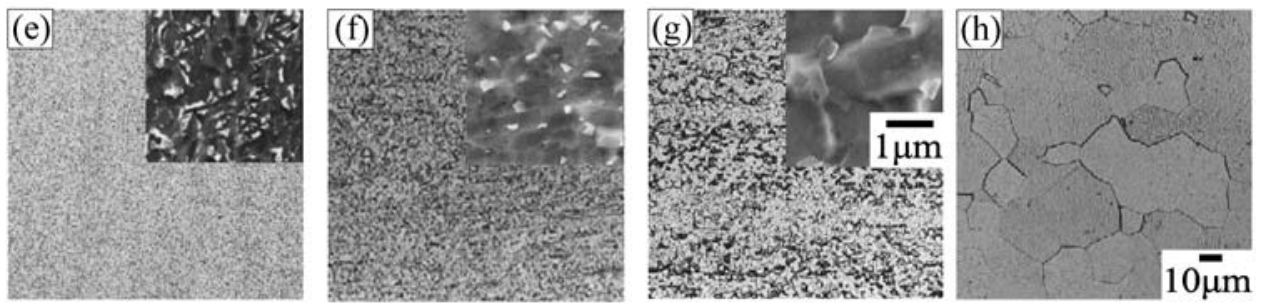

After hot-rolling - hydrogen desorption

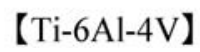

【Ti-3Al-2.5V】

【Ti-1Fe-0.35O】

【CP-Ti】

Fig. 9 Microstructure of Ti-6Al-4V (a), Ti-3Al-2.5V (b), Ti-1Fe-0.35O (c) and CP-Ti (d) after quenching from $\beta$ single phase region, and those of $\mathrm{Ti}-6 \mathrm{Al}-4 \mathrm{~V}(\mathrm{e}), \mathrm{Ti}-3 \mathrm{Al}-2.5 \mathrm{~V}(\mathrm{f}), \mathrm{Ti}-1 \mathrm{Fe}-0.35 \mathrm{O}(\mathrm{g})$ and $\mathrm{CP}-\mathrm{Ti}(\mathrm{h})$ after hot rolling-hydrogen desorption.

とを示唆する組織が観察されたが，溶体化・和化処理を行う ことで, 組織は表層部抢よび内部いずれも均一な針状組織と なる。

(3) 最適な圧延温度は, $\mathrm{Ti}-3 \mathrm{Al}-2.5 \mathrm{~V}$ は $753 \sim 903 \mathrm{~K}$, $\mathrm{Ti}-1 \mathrm{Fe}-0.35 \mathrm{O}$ は $713 \sim 763 \mathrm{~K}$ であり，この温度領域にて圧 延を行った場合，均一な等軸微細粒組織が得られる.

（4）同じく圧下率については, 圧下率が $40 \%$ の場合, 組 織の均一性に欠け，また一部に針状組織が残留するなど，完 全な等軸微細粒組織とはならないが, Ti-3Al-2.5V 合金で $60 \% ， \mathrm{Ti}-1 \mathrm{Fe}-0.35 \mathrm{O}$ 合金で $80 \%$ 以上にすることにより， 均一で等軸な超微細粒組織となる.

(5) 上記の最適な水素処理条件にて処理することにより, $\alpha+\beta 2$ 相型 $\mathrm{Ti}-3 \mathrm{Al}-2.5 \mathrm{~V}$ 合金および $\mathrm{Ti}-1 \mathrm{Fe}-0.35 \mathrm{O}$ 合金の 結晶粒径は $0.5 \sim 1 \mu \mathrm{m}$ の超微細粒組織となる. $\alpha$ 単相型の純 チタンについては若干の微細粒化の傾向を示すものの，その 粒径は約 $10 \mu \mathrm{m}$ 程度である。

（6）水素処理による微細粒化には水素吸蔵-溶体化・マル テンサイト $\left(\alpha^{\prime}\right)$ 化後に生じる微細な針状マルテンサイトが大 きく寄与しているものと考えられる.

(7) Ti-3Al-2.5V 合金および $\mathrm{Ti}-1 \mathrm{Fe}-0.35 \mathrm{O}$ 合金の耐力, 引張強さは超微細粒化とともに向上する. また, 超微細 $\mathrm{Ti}-$ $3 \mathrm{Al}-2.5 \mathrm{~V}$ 合金は温度 $1123 \mathrm{~K}$ ，初期歪み速度 $2 \times 10^{-3} \mathrm{~s}^{-1}$ に
おいて $9000 \%$ 以上もの大きな超塑性伸びを示す.

文献

1) H. Yoshimura, K. Kimura, M. Hayashi, M. Ishii and J. Takamura: J. Japan Inst. Metals 55(1991) 1375-1381.

2) H. Yoshimura, K. Kimura, M. Hayashi, M. Ishii, T. Hanamura and J. Takamura: J. Japan Inst. Metals 56 (1992) 1352-1359.

3) H. Yoshimura, Y. Fujii, S. Wada, A. Murakami and K. Kimura: J. Japan Inst. Metals 61 (1997) 83-89.

4) J. Nakahigashi and H. Yoshimura: J. Soc. Mat. Sci., Japan $49(2000)$ 1307-1311.

5) J. Nakahigashi and H. Yoshimura: J. Japan Inst. Metals, 65 (2001) 1096-1103.

6) J. Nakahigashi, K. Takahata, K. Tsuru, T. Sumimoto, H. Yoshimura and H. Horimura: Collected Abstracts of the 2005 Spring Meeting of the Japan Inst. Metals (2005) p. 238.

7) Rodney Boyer, Gerhard Welsch and E. W. Collings: Materials Properties Handbook: Titanium Alloys, (ASM International, 1994) p. 1111-1117.

8) R. Davis, H. M. Flower and D. R. F. West: J. Mater. Sci. 14(1979) 712-722.

9) E. S. K. Menon and R. Krishnan: J. Mater. Sci. 18(1983) 365374.

10) I. Weiss, F. H. Froes, D. Eylon and G. E. Welsh: Metall. Trans. A 17 (1986) 1935-1947.

11) H. Fujii and H. Suzuki: Testu to Hagane 77 (1991) 1481-1488.

12) H. Yoshimura: Materia Japan, 34(1995) 141-145. 